\title{
TAMBORA SEBUAH PERJALANAN VISUAL
}

\author{
Aka Kurnia S F ${ }^{*}$, M Syukron Anshori² \\ $1^{*}$ Fakultas IImu Komunikasi Universitas Teknologi Sumbawa \\ ${ }^{2}$ Fakultas IImu Komunikasi Universitas Teknologi Sumbawa \\ ${ }^{*}$ Corresponding Author email: ${ }^{1}$ aka.kurnia@uts.ac.id
}

\begin{tabular}{|c|c|}
\hline \multirow{4}{*}{$\begin{array}{l}\text { Diterima } \\
\text { Bulan Januari } \\
2020\end{array}$} & Abstrak \\
\hline & Tujuan dari penelitian ini adalah untuk merefleksikan kembali 200 tahun letusan \\
\hline & gunung Tambora yang berada di pulau Sumbawa Nusa Tenggara Barat melalui \\
\hline & perjalanan dengan pendekatankajian fotografi,khususnyatravel photography. \\
\hline & $\begin{array}{l}\text { Sejak awal kehadirannyafotografi telah memainkan peran secara konstitutif } \\
\text { dalam membentuk sebuah catatan perjalanan, hal ini juga sebanding dengan }\end{array}$ \\
\hline Diterbitkan & pentingnya peran tersebut sebagai penggambaran identitas sosial (Osborne, \\
\hline Bulan Februari & 2000). Selain itu, travel photography juga menjadi cara untuk melihat \\
\hline 2020 & $\begin{array}{l}\text { pengalaman melalui otentikasi visual (Hilman Wendy, 2007). Gunung Tambora } \\
\text { meletus pada April 1815, berdampak pada perubahan iklim dunia dan bencana } \\
\text { alam yang memakan korban } 84.000 \text { jiwa di pulau Sumbawa, serta mengubur }\end{array}$ \\
\hline Keyword: & kerajaan Tambora dan Pekat.. Berdasarkan hasil penelitian, peneliti melihat \\
\hline Komunikasi, & terjadinya rekonstruksi pemaknaan dalam sejarah letusan gunung Tambora yang \\
\hline Travel & tidak hanya dilihat sebagai sebuah gunung, namun juga sebagai sebuah identitas \\
\hline Photography, & dalam struktur sosial kemasyarakatan dalam bentuk karya fotografi. Seorang \\
\hline $\begin{array}{l}\text { Tambora, } 1815, \\
\text { Sumbawa, }\end{array}$ & $\begin{array}{l}\text { fotografer berperandalam menciptakan sebuah realitas sejak pre-travel hingga } \\
\text { post-travel. }\end{array}$ \\
\hline Climate Chanos & \\
\hline
\end{tabular}

Semiotika

\section{PENDAHULUAN}

Gunung Tambora meletus pada April 1815, berdampak pada perubahan iklim dunia dan bencana alam yang memakan korban 84.000 jiwa di pulau Sumbawa. Letusan gunung Tambora merupakan bencana alam yang multiefek, yang mengakibatkan tsunami, hujan abu, penyebaran penyakit, rusaknya sumber makanan-air, dan lain sebagainya.

Letusan Tambora tahun 1815 adalah letusan terbesar dalam sejarah manusia modern. Bunyi letusannya terdengar sejauh $2.600 \mathrm{~km}$, dan abu jatuh setidaknya sejauh $1.300 \mathrm{~km}$ dari Tambora. Menurut Smith sonian dari Museum of Natural History, letusan Tambora berkekuatan 7 Volcanic Explosivity Index. Hal ini menandakan letusan Tambora berkekuatan empat kali lebih kuat dari letusan gunung Krakatau tahun 1883. Energi letusannya setara dengan ledakan 171.500 unit bom atom. Dengan ini letusan Tambora menjadi letusan tebesar di abad modern, sejak letusan danau Taupo pada tahun 1815 .

Setelah meletus, Tambora kehilangan sepertiga tubuhnya. Ketinggian saat ini Tambora 2.851 meter dpl. Diameter kawah sekitar 6.000 meter, dengan luas 2.826 hektare, dalam 1.000 meter. Luasnya setara dengan 60 lapangan sepak bola. Sampai sekarang status Tambora masih sebagai stratovolcano aktif dan membentuk kaldera kering terbesar di Indonesia

\section{Dampak Letusan}

Letusan Tambora berdampak pada skala lokal, nasional dan internasional yang berlangsung dari tanggal 5-17 April yang mengubur dua kerajaan di sekitar Gunung Tambora, yakni kerajaan Tambora dan Kerajaan Pekat, dan sebagian Kerajaan Sanggar, Bima, Dompu dan juga Kerajaan Sumbawa.

Thomas Stamford Raffles Gubernur Hindia Timur (Hindia Belanda) yang merupakan kepanjangan tangan Kerajaan Inggris, Letusan Tambora pertama kali terdengar Pada tanggal 5 April 1815, diikuti dengan suara gemuruh (letusan) yang terdengar sampai ke beberapa daerah Indonesia, diantaranya di Makassar, Sulawesi (yang berjarak $380 \mathrm{~km}$ dari gunung Tambora), Batavia (kini Jakarta) di pulau Jawa (1.260 km), dan Ternate di Maluku $(1400 \mathrm{~km})$. Suara letusan ini terdengar sampai ke pulau Sumatera pada tanggal 10-11 April 1815 (lebih dari $2.600 \mathrm{~km}$ ) yang awalnya dianggap sebagai suara tembakan meriam musuh. Pada pagi hari tanggal 6 April 1815, abu vulkanik mulai jatuh di Jawa Timur dengan suara letusan baru berakhir pada tanggal 12 April 1815.

Catatan Rafles, dalam bukunya The History Of Java (2014:3);

"Ledakan pertama yang, ledakan pertama yang didengar di Pulau Jawa adalah di malam hari Pada tanggal 5 April; terdengar tiap 15 menit sekali sampai keesokan harinya tanggal 16., Suara yang pertama terdengar mirip dengan dengan bunyi meriam di kejauhan, sehingga kami mengira 
itu adalah pasukan dari Djocjocarta [Yogyakarta(ed.)] yang sedang diserang musuh, dan di sepanjang pantai mulai dilakukan pencarani kapal yang diserang.

Keesokan harinya, hujan abu pertama mulai turun dan menyingkirkan semua spekulasi asal suara ledakan. Selama berlangsungnya ledakan, suara itu bertambah keras sehingga terasa dekat dengan kami, dan kami mengira itu letusan dari Gunung Merapi, Klut atau Bromo. Pada Tanggal 6 April matahari hilang dari pandangan, dan disetiap tempat tertutup kabut. Udara panas dan sinar matahari masih belum tampak, dan dari getaran yang terasa akan menunjukkan adanya gempa bumi. Ini berlangsung sampai beberapa hari.

Letusan masih terjadi, tapi tidak sekeras dan sesering awalnya. Abu vulkanik mulai turun dalam jumlah kecil, bahkan tidak terlihat lagi di wilayah barat. Gejala alam ini masih terlihat sampai tanggal 10 April, hingga akhirnya mulai mereda dan tidak ada penyelidikan lebih lanjut. Namun di sore harinya letusannya mulai terdengar lebih keras dan lebih sering. Dari arah timur laut Cheribon, cuaca tampak gelap oleh turunnya hujan abu, Matahari menghilang lagi, dan di beberapa tempat, terutama di Solo dan Rembang, terasa ada getaran tanah yang hebat. Getaran ini lebih terasa di wilayah Timur, dimana letusan masih berlangsung sampai tanggal 11 dan getaran itu merusak beberapa rumah. Kegelapan sangat terlihat di sepanjang malam sampai keesokan harinya. Di Solo, lilin mulai dinyalakan dari jam 4 sore pada tanggal 12 , sementara di Magelan, di Kedu jarak pandang mencapai 300 yard. Di Gresik dan beberapa wilayah timur, dimana letusan masih berlangsung sampai tanggal 12 April, dimana angin mulai membawa ujan abu ke arah lain.

Di daerah Banyuwangi ketebalan abu mencapai 8 inchi, namun di Sumenep 2 Inchi, sedangkan di Gresik lebih kecil lagi, bahkan sinar matahari di Semarang sudah tidak terhalangi".

"Udara yang panas dan terik, serta masih turunnya hujan abu, berlangsung sampai tanggal 14 April dan di beberapa tempat dan bahkan sampai tanggal 17 April, hujan lebat kemudian membersihkan semuanya, dan setelah itu udara kembali jernih dan sejuk.

Tampaknya peristiwa ini mencegah kerusakan lebih lanjut, dan mencegah wabah penyakit yang mulai berjangkit, kecuali di Batavia, dimana selama 2-3hari turun hujansehingga banyak orang terserang demam. Tapi tidak ada kerugian material di luar daerah Banyuwangi. Para petani mencoba menghilangkan abu dari tanaman padi mereka, dan hujan yang turun mencegah perkembangan hama di akar padi yang berkembang selama hujan abu. Di Rembang, dimna tidak ada hujan sampai sampai tanggal 17, tiba-tiba terjadi hujan abu yang mengakibatkan lahan pertanian rusak parah. Di Banyuwangi bahkan menderitakerusakan terparah karena hujan abu paling kuat, sejumlah lahan pertanian rusak total, dan tanaman lain ikut rusak. 126 ekor kuda dan 86 ekor sapi mati karena kelaparan”.

Setelah beberapa hari peristiwa hujan abu, Rafles memerintahkan Letnan Owen Philips untuk mencari tahu apa yang terjadi.

"Karena raja menjadi saksi peristiwa tersebut, maka berikut ini keterangan di berikannya; Sekitar pukul 7 malam tanggal 10 April, terlihat 3 bola api besar keluar dari Gunung Tomboro (tampaknya berasal daridasar kawah) dan kemudian ketiga bolah api itu bergabung di udara dalam satu ledakan dahsyat.

Dalam waktu singkat seluruh gunung di dekat Sangir tampak seperti bola api raksasa yang meledak ke segala arah. Ledakan bola api tersebut sangat dahsyat sampai menimbulkan kegelapan yang diakibatkan berjatuahn isi gunung yang terjadi pukul 8 malam, hujan batu lebat terjadi di Sangirbeberapa diantaranya sebesar dua kepalan tangan, tapi rata-rata sebesar kerikil. Antara pukul9-10 malam, hujan abu mulai turun diiringi angin kencang, yang merobohkan hampir setiap desa di Sangir, dan menerbangkan atap-atap rumah.Di daerah Sangir yang berbatasan langsung dengan Temboro, kerusakannya lebih parah. Pohon-pohon besar tercabut dari akarnya dan terbang di udara bersama kumpulan manusia, ternak, dan benda-benda lain dalam pusaran angin topan (terbukti dengan adanya batang-batang kayu yang terapung di laut).

Gelombang laut setinggi lebih dari $12 \mathrm{kaki}$ menyapu bersih dataran Sangir yang kecil, menyapu menyapu setiap rumah dan apa saja yang di jangkau. Angin topan berlangsung selama 1 jam, tidak terjadi letusan selama angin topan, sampai jam 11 pagi. Mulai tengah malam hingga sore tanggal 11, bencana ini terus berlangsung, kemudian semuanya mulai reda, dan ledakan mulai terdengar sekali-sekali, tapi ledakan tidak berhenti sama sekali sampai 15 Juli. Di seluruh desa yang ada di Tomboro. Hanya desa Tempo yang berpenduduk 40 orang yang masih ada. Di Pekate Tidak ada rumah yang tersisa; 26 orang yang saat itu ada di Sumbawa adalah keseluruhan mereka yang selamat. Seluruh pohon dan tanaman di sepanjang sisi utra dan barat semenanjung hancur total, kecuali daerah dataran tinggi di ujung Desa Tomboro.

\section{Tambora Merubah Wajah Dunia}

Letusan Tambora mencapai lapisan stratosfer, dan menyebar seluas satu juta kilometer persegi atmosfer bumi, membentuk payung aerosol yang menghalangi sinar matahari untuk jatuh ke bumi, yang membuat eropa mengalami musim dingin yang berkepanjangan. 


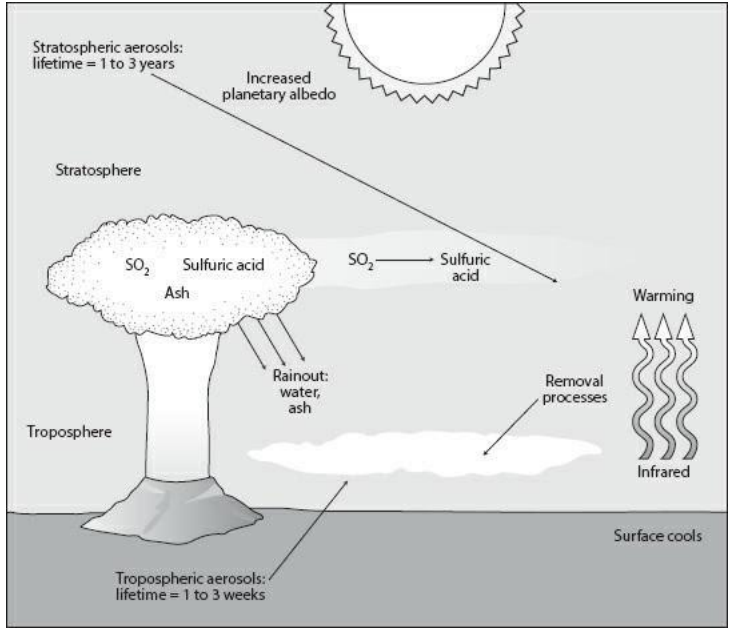

Gambar 1. Masuknya materi vulkanisyang lebih tinggi ke dalam atmosfer. (Wood, 2015 p. 68)

Di awali pada tahun 1816, setahun setelah letusan Gunung Tambora, negara-negara di eropa, dan asia mengalami tahun bencana berupa perubahan iklim yang ekstrim menjadikan lahan pertanian dan perkebunan ditutupi salju, dan hujan badai sehingga gagal panen yang menyebabkan kelaparan dan penyakit sebagai bencana kemanusian selama tiga tahun berturut-turut. Tahun 1816 di New England disebut tahun tanpa musim panas (the Year Without summer), 1817 di Jerman menyebutnya tahun pengemis, di swiss sebagai L Annee de la misere dan Das Hungerjhr (krisis sosial), di Swiss banyak warga lokal yang memakan daging kuda dan anjing untuk bertahan hidup dan ada juga yang memilih untuk membunuh anak-anak mereka sebagai cara yang paling manusiawi pada masa itu. Di Inggris terjadi kerusuhan serius, para buruh bersenjata dengan membawa slogan "roti atau darah". Periode inilah yang menjadikan gelombang besar migrasi masyarakat Eropa ke Amerika (Wood, Gilen D'arcy, Tambora 1815, Letusan Raksasa dari Indonesia (terj), Change; Jakarta, I 2015)

Setahun setelah Tambora meletus, menyebabkan perubahan iklim ekstrem, menjadikan suasana kegelapan dan meningkatnya suhu dingin di benua Eropa pada musim semi dan musim panas dalam rentang tahun 1816-1817, oleh warga Inggris waktu itu menyebutnya sebagai year without a summer, tahun tampa musim panas, dan warga New England, Amerika Serikat menjulukinya sebagai "eighteen hundred and froze to death".

Pada musim semi dan musim panas tahun 1816, sebuah kabut kering terlihat di timur laut Amerika Serikat. Kabut tersebut memerahkan dan mengurangi cahaya matahari, seperti bintik pada matahari yang terlihat dengan mata telanjang. Baik angin atau hujan tidak dapat menghilangkan "kabut" tersebut. "Kabut" tersebut diidentifikasikan sebagai kabut aerosol sulfat stratosfer. Pada musim panas tahun 1816, negara di Belahan Utara menderita karena kondisi cuaca yang berubah, Temperatur normal dunia berkurang sekitar $0,4-0,7{ }^{\circ} \mathrm{C}$, cukup untuk menyebabkan permasalahan pertanian di dunia.

Pada tanggal 4 Juni 1816, cuaca dingin dan dipenuhi es dilaporkan di Connecticut, dan dan pada hari berikutnya, hampir seluruh New England terasa sangat dingin. Pada tanggal 6 Juni 1816, salju turun di Albany, New York, dan Dennysville, Maine. Kondisi serupa muncul untuk setidaknya tiga bulan dan menyebabkan gagal panen di Amerika Utara. Kanada mengalami musim panas yang sangat dingin. Salju setebal $30 \mathrm{~cm}$ terhimpun didekat Kota Quebec dari tanggal 6 sampai 10 Juni 1816.

Letusan Tambora selain berdampak pada perubahan iklim ekstrim dan tragedi kemunusian, letusan ini melahiran karya-karya seni, ilmu pengetahuan, teknologi dan lain sebagainya. Lahirnya novel "Frankenstein" karya Mary Salley. Jhon Polidori yang menulis cerita vampire yang menginspirasi para pembuat film-film horror. Sajaksajak kegelapan "Drakness" karya Lord Byron. Sajak tujuh kesedihan oleh Wang Chan. Penggunaan warna baru dalam lukisan di Eropa, salah satunya lukisan karya Wiliem Turner, berupa langit-langit senja berwarna orange yang merupakan pantulan sinar matahari yang tertutup aeresol letusan Tambora. Ditemukan velocipeda sebagai cikal bakal sepeda yang dibuat oleh Baron Van Draisse sebagai solusi transportasi utama oleh kuda dan sapi yang mati akibat dibunuh dan kelaparan karena cuaca dingin di Jerman. Hasil penelitian Benyamin Franklin, berjudul " Imajinasi dan Rekaan Metereologis" membuktikan tentang gunung meletus yang berdampak pada perubahan iklim.

\section{Travel Photography}

Peneliti dalam melakuan pemotretan menggunan pendekatan Travel Photography peneliti merangkap juga sebagai fotografer melakukan perjalanan ke Tambora, menyusuri berbagai jalur darat, laut maupun udara. Sejak awal kehadirannya, fotografi telah memainkan peran secara konstitutif dalam membentuk sebuah catatan perjalanan, hal ini juga sebanding dengan pentingnya peran tersebut sebagai penggambaran identitas sosial (Osborne, 2000). Selain itu, travel photography juga menjadi cara untuk melihat pengalaman melalui otentikasi visual (Hilman Wendy, 2007).

Perjalanan darat dari Kabupaten Sumbawa - Cabang Soriutu Dompu- Dorocanga-Pancasila. Perjalanan laut dari Labuhan Badas-Pulau MoyoTeluk Saleh-Satonda-Labuhan Kenanga-Pancasila. Perjalanan Udara dari Jakarta-Denpasar-Bima, dilanjutkan dengan perjalanan darat ke Labuhan Kenanga. Perjalanan peneliti ada yang terjadwal mengikuti rombongan Memory of The Earth 2015 dan Moving Festival "Ziarah Tambora 2016". 
Pada 2016 peneliti melakukan perjalanan solo trevel tanpa terikat jadwal ke kaki Tambora. Peneliti memotret selama perjalanan tentang manusia, alam, budaya, dan berbagai hal yang menarik yang berhubungan dengan ingatan-ingatan tentang gunung Tambora. Teknis dalam memotret, peneliti lebih sering memotret dengan candid tanpa mengatur objek, dan menunggu sesuatu terjadi untuk mendapatkan momen terbaik, yang disebut oleh Henri Cartier Bresson sebagai The Decisive Moment

Menurut Jhon Berger, kegiatan memotret dan menentukan pilihan tentang apa yang dipotret merupakan suatu kontruksi budaya. Konstruksi itu merupakan suatu pembacaan atas peristiwa, yang intuitif dan berlangsung cepat sekali, memutuskan dengan segera pilihan atas objeknya. Pilihan ini akan sangat ditentukan oleh situasi sosial dan kehidupan pemotret, yang merupakan suatu rgument, suatu pengalaman, suatu cara menjelaskan dunia" (Simon, Steve. 2011. The Passionate Photographer; 10 Langka Menjadi Fotografer Yang Hebat, Jakarta; Elek Media Komputindo. Hal 82)

\section{Hasil Karya dan Pembahasan}

Sebuah buku foto, berdasarkan perjalanan ke Tambora dengan gaya travel photography, dan dalam menampilkan karya foto tersebut, dalam bentuk buku yang berisi foto-foto dan ingataningatan tentang gunung Tambora melalui pengalaman pribadi maupun referensi sekunder maupun primer.

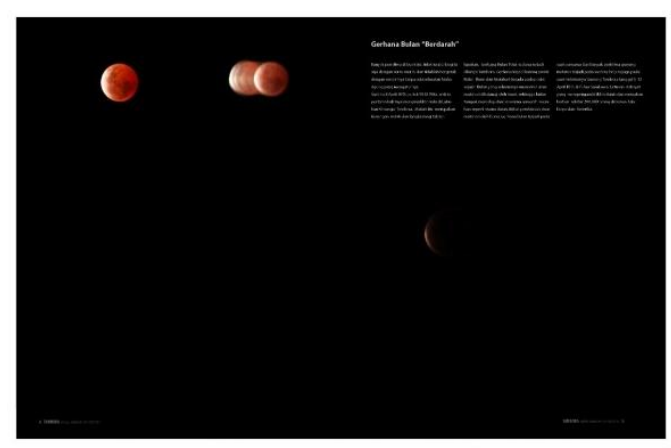

Gambar 2. Gerhana Bulan Berdarah

(Foto; Aka Kurnia SF)

Banyak peristiwa di bumi ini, tidak terjadi begitu saja dengan serta merta, dan tidaklah bergerak dengan sendirinya tanpa ada kekuatan Maha dahsyat yang mengaturnya.Saat itu 4 April 2015, pukul 19.42 Wita, waktu pertama kali saya menginjakkan kaki di Labuhan Kenanga, Tambora. Malam itu merupakan kenangan indah dan langka yang tak terlupakan, Gerhana Bulan Total sedang terjadi dilangit Tambora. Gerhana terjadi karena posisi Bulan, Bumi dan Matahari berada pada posisi sejajar, bulan yang seharusnya menerima sinar matahari namun terhalang oleh posisi bumi, sehingga bulan tampak meredup dan berwarna kemerah-merahan seperti warna darah akibat pembiasan sinar matahari oleh bumi.

Dalam ilmu astronomi, kesejajaran ini disebut sebagai "syzygy". Gerhana Bulan terjadi pada saat purnama. Banyak peristiwa Gunung melatus terjadi pada saat purnama atau bulan baru, begitu juga pada saat meletusnya gunung Tambora tanggal 5-12 April 1815 di Pulau Sumbawa, yang mempengaruhi Iklim dunia dan banyaknya korban jiwa. Menurut Heinrich Zollinger korban meninggal di Pulau Sumbawa, jumlah keseluruhan sekitar 84.000 jiwa, 10.000 jiwa meninggal karena letusan, 38.000 jiwa karena kelaparan, dan 36.000 jiwa karena wabah penyakit.

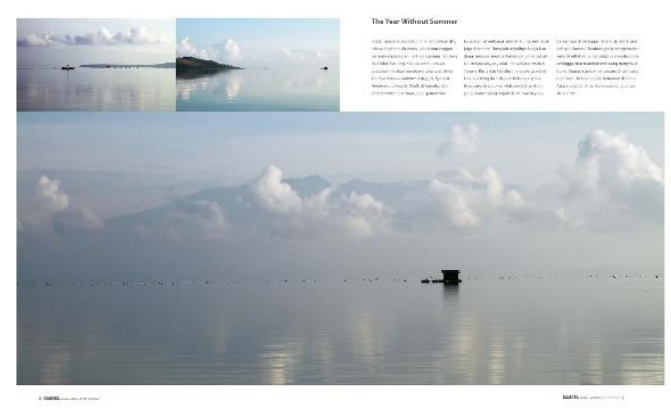

Gambar 3. A year Without Summer (Foto; Aka Kurnia SF)

Sosok matahari pagi belum menampakkan diri, udara dingin masih terasa, kabut pun enggan beranjak ke peraduan. Terlihat Gunung Tambora dari Teluk Santong, Sumbawa. Seakan membayangkan peristiwa The Year Without Summer di Inggris, Eghteen Hundred and Froze to Death di Amerika, Jahr ohne Sommer di Jerman, gagal panen dan kelaparan yang akut di Yunnan Tiongkok, penyebaran wabah Tipus di Rusia dan Irlandia, merebaknya wabah kolera di Benggala India dan beberapa peristiwa yang disebabkan oleh perubahan iklim yang terjadi dalam waktu yang bersamaan di berbagai negara, akibat aerasol letusan dahsyat Gunung Tambora yang menutupi cakrawala dunia, sehingga sinar matahari terhalang menyinari bumi. Suasana gelap mencekam, cuaca dingin yang membeku, kelaparan dan kematian di Benua Asia, Eropa dan Amerika di sepanjang tahun 1816-1819. 


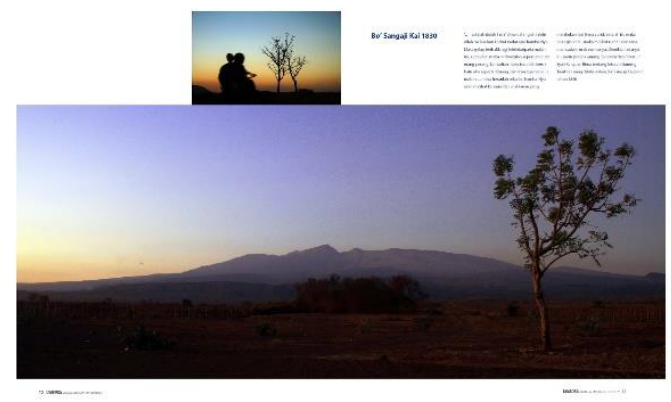

Gambar 4. Bo' Sangaji Kai 1830

(Foto; Aka Kurnia SF)

“... Tatkalah itulah Tana' Bima datanglah takdir Allah melakukan kodrat iradat atas hambaNya. Maka gelap berbalik lagi lebih daripada malam itu, kemudian maka berbunyilah seperti meriam orang perang, kemudian maka turunlah kersik batu abu seperti dituang, lamanya tiga hari dua malam. ... maka heranlah sekalian hamba-Nya akan melihat karunia Rabbil al-lamin yang melakukan faal li-ma yurid. Setelah itu maka teranglah hari, maka melihat rumah dan tanaman sudah rusak semuanya. Demikian adanya itu, yaitu pecah Gunung Tambora dan Pekat ..."

(Syair Kerajaan Bima tentang letusan GunungTambora yang ditulis dalam Bo' Sangaji Kai pada tahun 1830)

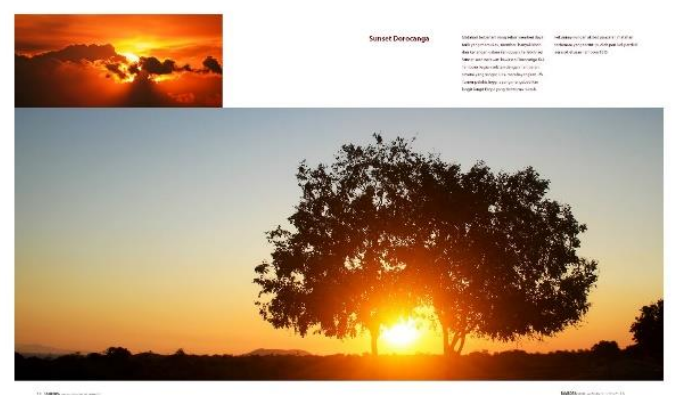

Gambar 5. Sunset Doro Ncanga (Foto; Aka Kurnia SF)

Matahari terbenam yang selau memberi daya tarik yang memukau, memberi banyak kisah dan kenangan dalam kehidupan, terlebih lagi Sunset saat melewati kawasan Doro Ncanga Kaki Tambora bagian selatan dengan hamparan savana yang sangat luas. membayangkan J.W Turner pelukis Inggris yang mengabadikan langit-langit Eropa yang berwarna merah kekuning-kuningan akibat pancaran matahari terbenam yang tertutup oleh partikel-partikel aerosol letusan Tambora 1815. Matahari memberi energi-energi kehidupan

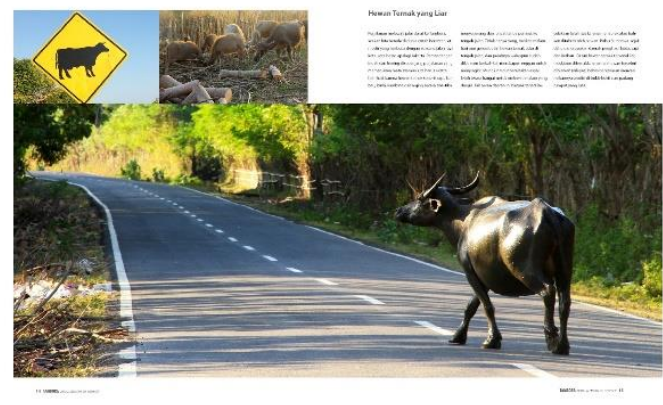

Gambar 6.Hewan Ternak yang Liar (Foto; Aka Kurnia SF)

Perjalanan melewati jalur darat ke Tambora sunguh menyenangkan, seakan kita berada di dunia antah berantah, atmosfer yang berbeda dengan suasana jalan raya kota besar di pulau Jawa, apalagi Jakarta. Pemandangan indah dan hening di sepanjang perjalanan yang memanjakan mata, namun kita harus ekstra hati-hati karena hewan ternak seperti sapi, kerbau, kuda dan kambing secara tiba-tiba menyeberang dan loncat tanpa permisi ke tengah jalan. Bahkan gerombolan anjing pun tak mau kalah untuk berkeliaran di jalanan. Tidak hanya siang bahkan malam hari pun banyak hewan ternak yang tidur di tengah jalan, dan parahnya walaupun sudah di klakson berkali-kali mereka pun enggan untuk menyingkir. Mungkin karena sepi dan jarang ada kendaraan yang lewat, serta tidur beralaskan aspal lebih terasa hangat untuk melewati malam yang dingin.

Tak heran di daerah ini banyak terjadi kecelakaan lalulintas karena menabrak atau bahkan ditabrak oleh hewan. Pulau Sumbawa sejak dahulu merupakan daerah penghasil kuda dan kerbau. Di sini hewan ternak terkenal liar, meskipun diternakkan namun hewan tersebut dibiarkan (dilepas) bebas berkeliaran mencari makannya sendiri di bukit-bukit dan padang savana.

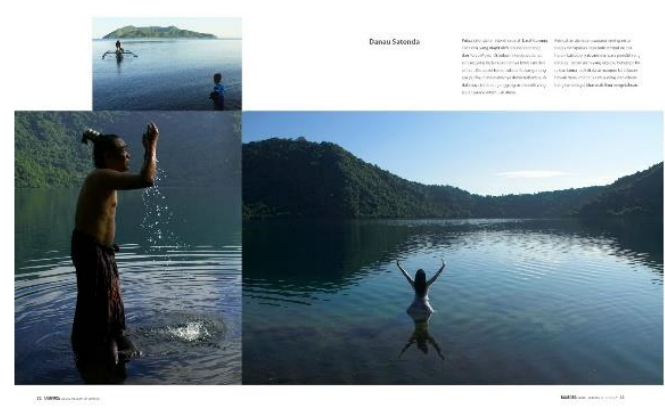

Gambar 7. Danau Satonda (Foto; Aka Kurnia SF)

Pulau Satonda terletak di sebelah barat Gunung Tambora, yang diapit oleh labuhan 
Kenanga dan Pulau Moyo. Di pulau ini terdapat danau air asin, yang kadar keasinannya lebih asin dari air laut. Danau ini terbentuk dari bekas gunung api purba, di masa awalnya dunia terbentuk, di dalamnya terdapat ganggang stromatolit yang sudah jarang ditemui di dunia. Keindahan alam dan suasana hening serta magis merupakan daya tarik tempat ini, tak heran kalau banyak turis dan para peneliti yang datang. Selain alam yang eksotik, beberapa flora dan fauna baik di darat maupun kehidupan bawah danau menarik untuk dikaji dan dikem-bangkan sebagai khasanah ilmu pengetahuan.

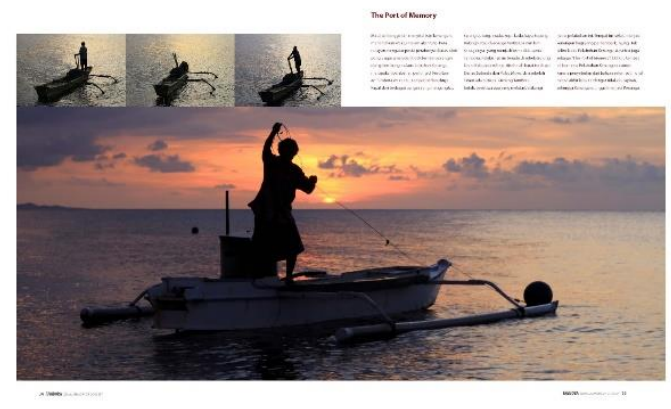

Gambar 8. The Port of Memory (Foto; Aka Kurnia SF)

Matahari tenggelam menyisakan kenangan, menandakan waktu malam akan tiba. Para nelayan mengatur posisi perahunya di atas bibir pantai, agar aman dan tidak terhempas angin dan gelombang malam. Labuhan Kenanga merupakan pelabuhan penting di Kesultanan Tambora waktu itu, tempat berlabuhnya kapal dari berbagai bangsa yang mengangkut sarang burung, madu, kopi, kuda, kayu Sepang, Kalango atau duabanga moluccana dan lain sebagainya, yang menjadi komoditi utama Tambora. Pelabuhan ini berada di sebelah ujung Utara Kabupaten Bima, disebelah barat terdapat Danau Satonda dan Pulau Moyo, dan sebelah Timur ada puncak Gunung Tambora. Entah, peristiwa apa yang melatarbelakangi nama pelabuhan ini. Tempat ini selalu menjadi kenangan bagi yang pernah berkunjung. Tak keliru kalau Pelabuhan Kenanga, disebut juga sebagai “The Port of Memory". Dahulu tempat ini bernama Pelabuhan Kenangan, namun karena penyebutan dari bahasa setempat, huruf mati diakhir kata, terdengar tidak diucapkan, sehingga kenangan, tinggal menjadi Kenanga.

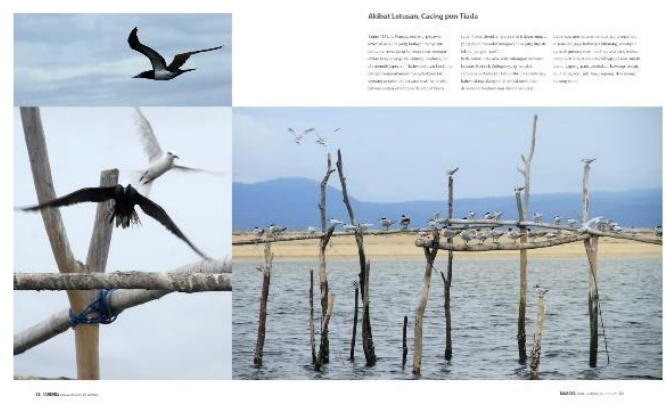

Gambar 9. Akibat Letusan, Cacing pun Tiada (Foto; Aka Kurnia SF)

Tahun 1831, E. Prancis, seorang pegawai kolonial Belanda yang berlayar menyusuri pantai semenanjung Sumbawa dan mengarahkan teropongnya ke Gunung Tambora, lalu dia menulis laporan, "bahwa letusan Tambora dengan kemarahannya menyebabkan tak seorang penduduk pun yang masih menyisa, bahkan seekor cacing pun dari dunia fauna sudah tiada, demikian pula sehelai daun rumput yang dapat mewakili kerajaan flora yang luas itu tak kunjung tampak".

Pada Tahun 1847 ada perkembangan menurut laporan Heinrich Zolinger yang mendaki Tambora pertama kali tahun 1847 pasca letusan, bahwa alang-alang sudah mulai tumbuh di di Gunung Tambora dan dia menemukan beberapa spesies tanaman dari pohon-pohon disana dan juga beberapa binatang, walaupun puncak gunung masih terlihat telanjang mulus. namun Di Bima menurut Zollinger, disana sudah panen jagung, padi, tembakau, bawang merah, gula-tebu, kopi, nila, kayu sepang, dan sarang burung walet.

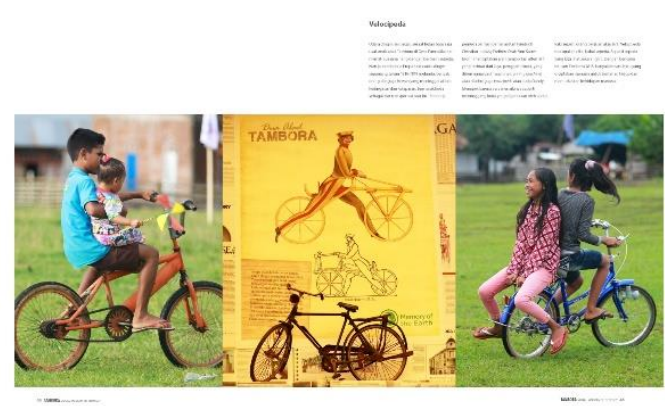

Gambar 10. Velocipeda

(Foto; Aka Kurnia SF)

Udara dingin nan segar sesaat hujan baru saja usai, anak-anak Tambora di Desa Pancasila menikmati suasana dengan sepedanya. Nun jauh di benua Eropa saat cuaca dingin sepanjang tahun 1816-1819 melanda, banyak manusia dan juga hewan yang meninggal akibat kedinginan dan kelaparan, termasuk kuda sebagai alat transportasi saat itu. Seorang pemuda Jerman bernama Karl 
Friedrich Christian Ludwig Freiherr Drais Von Sauerbronn menciptakan alat transportasi alternatif sebagai pengganti kuda, yang di beri nama Laufmaschine (running machine) atau disebut juga velocipede atau kuda Dandy (draisine), alat ini sebagai cikal bakal sepeda.

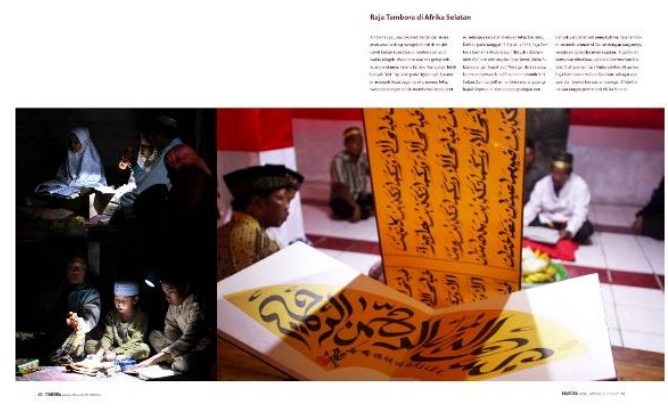

Gambar 11. Raja Tambora di Afrika Selatan (Foto; Aka Kurnia SF)

Alif-ba-ta-sya... Sayub-sayub terdengar suara anak-anak sedang mengeja huruf di masjid dekat kebun kopi dusun Tambora sehabis waktu Magrib. Walaupun suasana gelap terkadang melanda, karena listrik di tempat ini lebih banyak "pet"-nya dari pada "nyalanya". Susana ini menjadi biasa bagi mereka, namun tetap waspada dengan selalu membawa lampu senter, sehingga kegiatan mengaji tetap berjalan.

Dahulu pada tanggal 13 Agustus 1667, Raja Tambora bernama Abdul Basyir Nilaudin ditahan oleh VOC dan dibuang ke Cape Town, Afrika Selatan, dengan kapal laut "Voyage" dari Batavia, karena melawan dan difitnah membunuh Istri sultan Dompu. Sultan Tambora seorang penghafal Al Qur'an, di tempat pengasingan pun banyak yang menjadi pengikutnya. Raja Tambora menulis sebuah Al Qur'an dengan tangannya sendiri yang berdasarkan ingatan. Al Qur'an ini kemudian diberikan kepada Gubernur Van Der Stel. Oleh pemerintah Afrika Selatan Al qur'an Raja Tambora tersebut dijadikan sebagai warisan dan benda bersejarah, sebagai Al Qur'an tulisan tangan pertama di Afrika Selatan. Raja Tambora menikah dengan putri Syeh Yusuf Al Makasari dari Sulawesi.

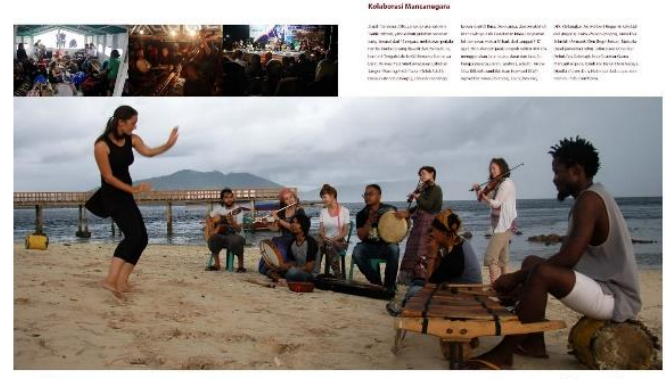

Gambar 12. Kolaborasi Mancanegara (Foto; Aka Kurnia SF)
Ziarah Tambora 2016, yang diprakarsai oleh Taufik Rahzen, yang diikuti puluhan seniman yang berasal dari 13 negara, melakukan perjalanan ke Tambora yang diawali dari Pantai Kutai, Lombok Tengah, lalu ke Gili Kenawa Sumbawa Barat, Wisma Praja Sumbawa Besar, Labuhan Sangur (Maronge), Gili Tapan (Teluk Saleh), Danau Satonda (Dompu), Labuhan Kenanga, kebun Kopi Oi Bura, Dorocanga, dan berakhir di istana Mbojo Asih Kesultanan Bima. Perjalanan ini memakan waktu 10 hari, dari tanggal 7-17 April 2016. dengan jarak tempuh sekitar $400 \mathrm{~km}$, menggunakan jalur udara, darat dan laut. Beberapa peserta Ziarah Tambora, adalah; Arone Silva Billa (Mozambik), Sean Hayward (USA), Agniezka Umma (Polandia), Leon (Mexsiko), Dilki (Srilangka), Jade Gilbert (Inggris), Kate Lid-dell (Inggris), Anita Watson (Inggris), Anna Thu Schmidt (Jerman), Ellen Begw Jordan, Mustofa Daod (Amerika/Debu), Salim Daod (Amerika/Debu), Ray Sahetapi, Jean Couteau, Gaura Mancacaritadipura, Bambang Besur, Heru Mataya, Dinullah Rayes, Doly Nofer, dan beberapa seniman se- Pulau Sumbawa.

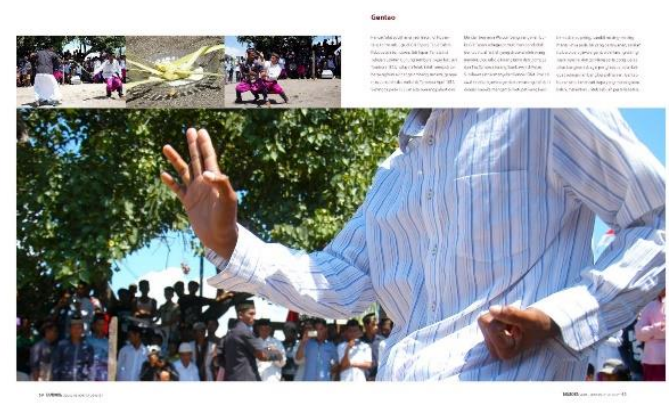

Gambar 13. Gentao

(Foto; Aka Kurnia SF)

Pancak Silat sudah menjadi tradisi di Nusantara, termasuk juga di Gili Tapan, wilayah Teluk Saleh, Kabupaten Sumbawa. Gili Tapan Terletak di sebelah Selatan Gunung Tambora. Sejak letusan Tambora 1815, Teluk Saleh menjadi tak berpenghuni akibat gelombang tsunami, gempa maupun oleh abu vulkanik Tambora April 1815. Sehingga pada 1930an ada seorang pelaut dari Mandar bernama Wa Lombeng yang membuka Gili Tapan sebagai pemukiman penduduk. Gentao itulah istilah yang dipakai oleh orang mandar, Dou Mbojo (orang Bima dan Dompu), dan Tau Samawa (orang Sumbawa) di Pulau Sumbawa untuk menyebut Pencak Silat.

Prosesi awal sebelum jawara gentao bertarung, terlebih dahulu mereka mengambil ketupat yang berisi beras di atas piring, sambil masing-masing menariknya pada sisi yang berlawanan, setelah itu baru para jawara gentao bertarung diiringi suara serunai dan gendang serta gong. Beras dilambangkan sebagai penghidupan dan ketupat sebagai lambang kesejahteraan. Gentao 
bukan untuk mencari siapa yang menang atau kalah, melainkan untuk sebuah persahabatan.

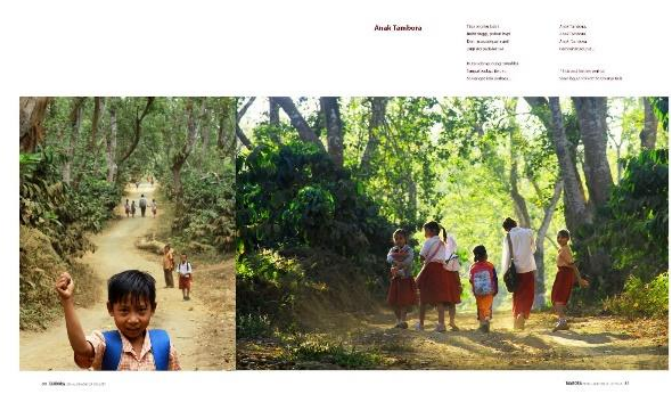

Gambar 14. Anak Tambora (Foto; Aka Kurnia SF)

Tiap pagi ku jalani; Bukit tinggi; Pohon kopi; Demi masa depan nanti; Janji sici pada lertiwi; Hutan dan gunung rumahku; Sungai budaya jiwaku; Semangat kaki perkasa...; Anak Tambora, Anak Tambora; Anak Tambora Pembaharu dunia...;

* Sici: suci, lertiwi: pertiwi

Syair lagu Anak Tambora karya Kris

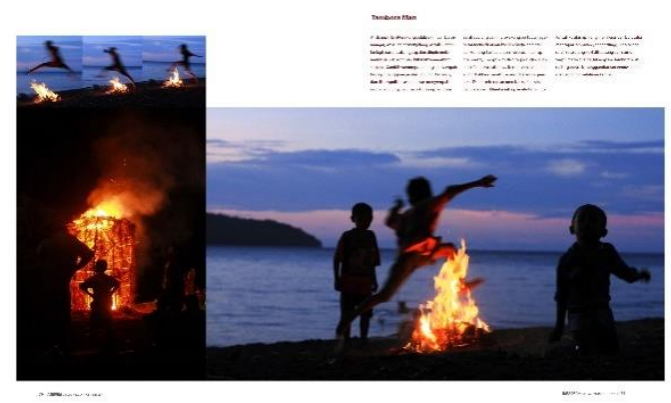

Gambar 15. Tambora Man (Foto; Aka Kurnia SF)

Anak-anak Tambora yang selalu aktif dan bersemangat, waktu telah menjelang Magrib. Sebentar lagi suasana akan gelap dan dingin mulai menyapa, suara ombak ikut menyemarakkan suasana. Sambil memungut ranting dan sampah kering di pinggiran pantai Labuhan Kenanga, dan dikumpulkan seakan-akan menyerupai sebuah gunung, sosok Gunung Tambora. Salah seorang dari mereka yang bertubuh agak besar mengeluarkan korek sebagai pemetik api. Gunung Tambora pun meletus, lidah api membesar, menyala-nyala diterpa angin. Anak-anak Tambora bukannya bertambah takut atau kuatir, bahkan mereka semakin bersorak gembira. Darah keberanian mereka ikut tersulut dan berkobar. Mereka saling berebutan untuk loncat ke atas api yang membara, dan berusaha mencapai lompatan yang tertinggi. Terkadang salah satu ujung kaki dijilat sang api, namun wajah mereka selalu tersenyum. Tambora Man sedang beraksi, menggambarkan pemusnahan dan semangat kelahiran kembali.

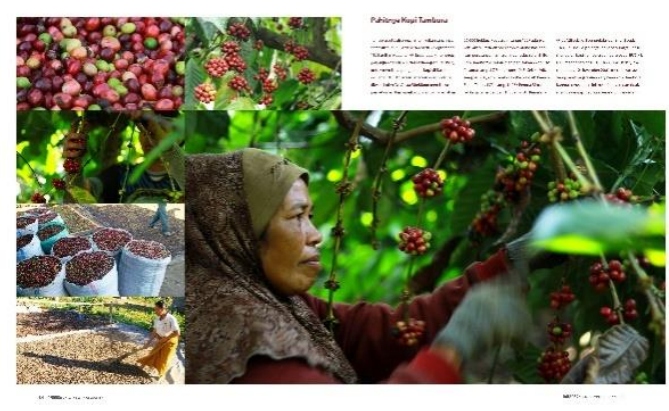

Gambar 16.Pahitnya Kopi Tambora (Foto; Aka Kurnia SF)

Tambora setelah erupsi, menjadikan tanahnya semakin subur. Tidak heran pada 7 September 1893 Sultan Abdullah (Raja Sanggar) membuat perjanjian dengan D. Nelles (Kerajaan Belanda) untuk membuat pengolahan kopi di Tambora. Pada 1930 Koperasi Federasi Swedia yang diwakili oleh Dr. Gosta Bjorklund membuka perkebunan dan pabrik kopi dengan luas lahan 56.000 hektar. Pada akhir tahun 1957 adanya kebijakan Presiden Soekarno tentang nasionalisasi perusahaan asing di Indonesia. Setelah itu Kopi Tambora dikelola oleh perusahaan kopi NV Pesuma sampai 7 September 1968. Sejak 1968 sampai 1970, kopi Tambora dikelola oleh Pemda Bima.

Tahun 1971 sampai 1973 Pemda Bima bekerjasama dengan PT. Banyu Aji Bimasena (PT. BAB) sebagai pengelola, dan mulai pada 1974, PT. BAB dipercayakan sepenuhnya untuk mengolah kopi Tambora dan baru pada 1976 PT. BAB mendapatkan HGU (Hak Guna Usaha). Namun pada 10 November 2001, merupakan awal yang pahit bagi ribuan karyawan kopi Tambora, karena perusahaan ini melarikan diri dan tidak membayar gaji maupun pesangon karyawan.

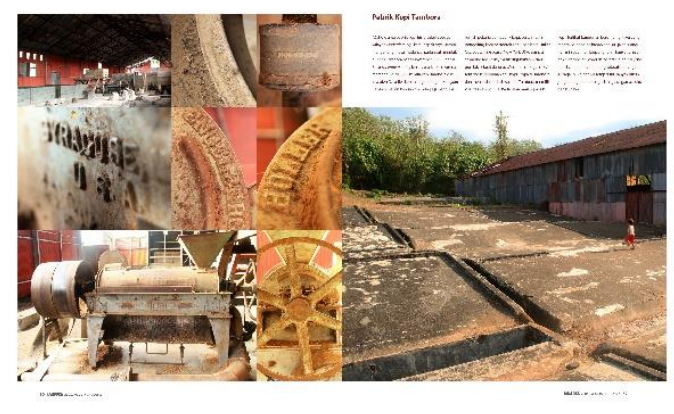

Gambar 17. Pabrik Kopi Tambora

(Foto; Aka Kurnia SF)

"Dahulu area pabrik kopi ini, disebut sebagai wilayah Onderdeming", kata bapak saya, 
sambil mengenang pada saat mendaki puncak Tambora pada November 1971. Bahasa Belanda onderdeming bermakna kebun, karena memang sejak 1893 kebun kopi Tambora dikelola oleh D. Nelles kepanjangan tangan Kerajaan Belanda. Selain kebun kopi, ada juga bangunan rumah pekerja dan pabrik kopi, serta mesin penggiling kopi bermerek The Engelberg Huller Co., buatan Syracuse, New York USA, sampai sekarang mesin ini, masih digunakan walaupun tak sekuat dahulu. Mesin ini sebagai saksi tentang keberadaan ahli kopi Eropa di Tambora, dan menandakan bahwa kopi Tambora memiliki kualitas kelas dunia.

Pada jalan masuk pabrik kopi, terlihat bangunan berdinding kayu yang terletak di sebelah kanan dan kiri jalan. Bangunan ini sudah tak berpenghuni, hanya tersisa bekas tempelan, coretancoretan dinding yang berisi curahan hati tentang sebuah kenangan, sebagai bukti bahwa tempat ini banyak dikunjungi orang dari berbagai bangsa, agama, suku dan budaya.

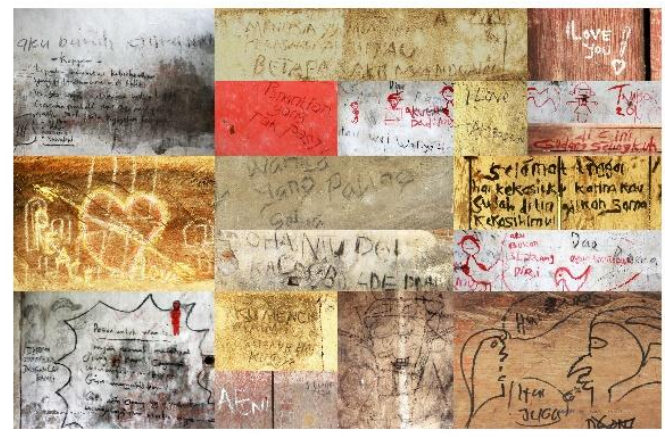

Gambar 18.Coretan Hati

(Foto; Aka Kurnia SF)

Coretan di dinding kamar kayu karyawan perkebunan kopi Tambora di OI Bura, sebagai saksi visual, yang disusun menjadi artistik

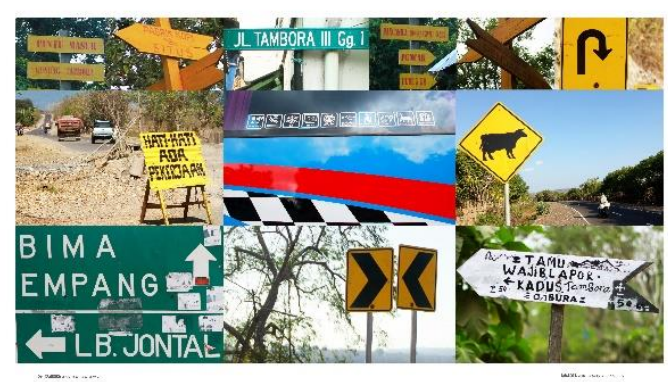

Gambar 19. Sign

(Foto; Aka Kurnia SF)

Petunjuk arah sepanjang jalan ke Tambora

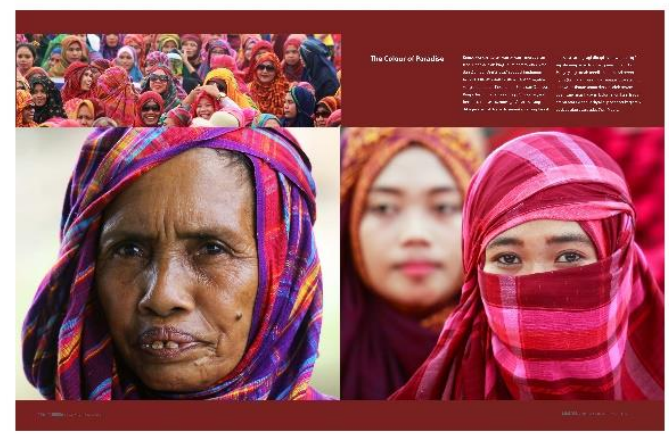

Gambar 20. The Colour of Paradise (Foto; Aka Kurnia SF)

Rimpu dengan corak warna-warni merupakan tradisi berpakaian bagi kaum perempuan Bima dan Dompu (Dou' Mbojo) sebagai implementasi dari nilai etik dalam Islam, sebagai agama yang dianut oleh Kesultanan Bima dan Dompu. Rimpu terdiri dari dua sarung (dua ndo'o) yang berupa tenun asli (tembe ngoli), satu sarung dibagian bawah (seperti memakai sarung biasa) dan satu sarung lagi dibagian atas, menutupi kepala sampai badan. Bagi perempuan Dou' Mbojo yang sudah menikah memakai rimpu mpa'i (kelihatan wajah) dan Rimpu Cole atau Cili (hanya kelihatan mata) dipakai oleh perem-puan yang masih gadis, belum menikah. Tradisi rimpu saat ini hanya dipakai pada saat kegiatan budaya atau acara adat Dou' Mbojo.

\section{PENUTUP}

\section{Kesimpulan}

1. Rekontruksi dokumen perjalanan berdasarkan ingatan visual tentang Tambora, baik Tambora masa lalu, masa kini, dan harapan ke depan.

2. Seorang fotografer ikut serta menciptakan realitasnya, pada penyelenggaraan perjalanan, perjalanan berkarya dan sesudahnya

3. Menambah pendekatan baru pada tradisi fotografi Indonesia

\section{REFERENSI}

Boer, Bernice de Joeng \& SJamsuddin, Helius. 2012. Letusan Tambora 1518. Yogyakarta; Ombak

Gumira Aji Darma, Seno. 2002. Kisah Mata (Fotografi Diantara Dua Subyek: Perbincangan Tentang Ada), Galang Press:Yogyakarta,

Kurnia SF,Aka. 2016. Tambora ;Visual Memory Of Odyssey (Tesis). Jakarta; Pascasarjana IKJ 
Excell.Laurie dkk.. 2011. Komposisi (Dari Foto Biasa Jadi Luar Biasa), Jakarta;Elek Media Komputindo

Raffles, Thomas Stanford. 2014. History of Java (Terj. ). Jakarta; Gramedia

Sastha, Harley Bayu \& Wicaksono, Dedi. 2015. Menuju Puncak Gunung Tambora, Panduan Mendaki Gunung Tambora. NTB;BKSD
Tempo. 2015. 200 Tahun Tambora. Jakarta; Kepustakaan Populer Gramedia

Wood, Gilen D'arcy. 2015. Tambora 1815, Letusan Raksasa dari Indonesia (Terj), Change; Jakarta

Simon, Stave. 2014 The Passionate Photographer, 